\title{
university
of the arts
london
}

\begin{tabular}{|l|l|}
\hline Title & The invention of facts: Bentham's ethics and the education of public taste \\
\hline Type & Article \\
\hline URL & http://ualresearchonline.arts.ac.uk/4315/ \\
\hline Date & 2011 \\
\hline Citation & $\begin{array}{l}\text { Quinn, Malcolm (2011) The invention of facts: Bentham's ethics and the } \\
\text { education of public taste. Revue d'études benthamiennes: The Journal of } \\
\text { Bentham Studies. ISSN 17607507 }\end{array}$ \\
\hline Creators & Quinn, Malcolm \\
\hline
\end{tabular}

\section{Usage Guidelines}

Please refer to usage guidelines at http://ualresearchonline.arts.ac.uk/policies.html or alternatively contact ualresearchonline@ arts.ac.uk.

License: Creative Commons Attribution Non-commercial No Derivatives

Unless otherwise stated, copyright owned by the author 
$\underline{\text { Navigation }}-\underline{\text { Plan du site }}$

Centre Bentham

\section{Revue d'études benthamiennes}

Langue du site Français OK

$\underline{\text { Accueil }}>\underline{\text { Numéros }}>\underline{9}>\underline{\text { Dossier }}>$ The Invention of Facts: Bentham's Et (...)

Recherche

Chercher

$\underline{\text { Sommaire - Document précédent - Document suivant }}$

9 9 2011 : Éthique utilitariste

Dossier

\section{The Invention of Facts: Bentham's Ethics and the Education of Public Taste}

\section{Malcolm Quinn}

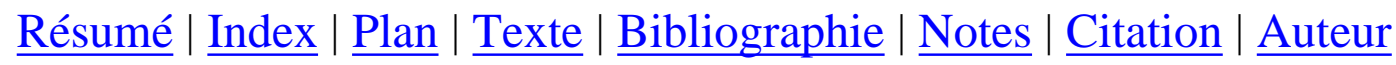

\section{Résumés}

\section{$\underline{\text { Français English }}$}

Le présent article porte sur les commentaires de Jeremy Bentham en matière de goût et d'éthique. Il analyse les efforts des représentants du « radicalisme philosophique » (notamment John Bowring) au sein du Comité consultatif des Arts et des Manufactures de 1835/6 et montre comment ils ont cherché à appliquer l'utilitarisme aux questions relatives public taste. Cet épisode inattendu soulève des problèmes 
d'éthique, de gouvernance et de pédagogie publique qui sont toujours d'actualité. Bentham avait élaboré une approche utilitariste du goût dans ses « Maximes relatives à la manière de transplanter les lois », où la correspondance entre les individus et les goûts était présentée comme une série d'affirmations contingentes au sein d'un système de signification. Une telle description est problématique car elle remet en cause « les préjugés personnels formés par des intérêts sectaires » qui s'expriment par le biais d'appréciations de sympathie ou d'antipathie. Mon analyse des problèmes découlant de la volonté de Bentham de mettre les 'préjugés à part' dans les discussions sur le goût, se fonde sur les analyses que fait Lacan de la 'conversion utilitariste'. L'éloge que Lacan fait de Bentham et de sa 'Théorie des Fictions' sous-estime l'importance de l'éthique benthamienne, tout en interprétant de façon erronée certaines de ses caractéristiques les plus importantes. Je soutiens que la façon dont Bentham traite les faits, plutôt que la fiction, permet une compréhension plus précise de la place de l'inconscient dans la pensée benthamienne, de même qu'une meilleure perception de la conscience utilitariste en matière de goût.

This article uses Jeremy Bentham's comments on taste and ethics to analyse the efforts of 'Philosophical Radical' members of the Select Committee on Arts and Manufactures of 1835/6, including Bentham's executor and editor John Bowring, to apply utilitarianism to questions of public taste. The application of utilitarian thinking to questions of public taste by Members of Parliament was an unlikely occurrence, but it raised problems of ethics, governance and public pedagogy that persist to this day. Bentham had sketched out a utilitarian approach to public taste in his writing on 'Rules Respecting the Method of Transplanting Laws', where the correspondence between individuals and tastes is presented as a set of contingent statements within a signifying system. However, the problem of describing taste as a set of contingent statements is that it challenges the 'interest begotten prejudice' that may be expressed in judgments of sympathy or antipathy. My analysis of the problems attending Bentham's wish to set 'prejudice apart' in discussions of taste, is undertaken with specific reference to the psychoanalyst Jacques Lacan's emphasis on the importance of what he termed 'the utilitarian conversion' in ethics. Lacan's praise for Bentham and the 'Theory of Fictions' demonstrates a limited insight into the importance of Bentham's ethics, while misunderstanding some of its most important features. I argue that Bentham's treatment of fact, rather than fiction, gives us a more precise route to the place of the unconscious in Bentham's thought, as well as a better understanding of a utilitarian consciousness of taste.

$\underline{\text { Haut de page }}$

\section{Entrées d'index}

\section{Index de mots-clés :}

$\underline{\text { Lacan, Bentham, goût, public, préjugés }}$

\section{Index by keyword :}


Bentham, Lacan, taste, public, prejudice

Haut de page

\section{Plan}

\section{1: Introduction}

2: Taste as Fact

3: The Unconscious

4: Conclusion - the task of the legislator

Haut de page

\section{Texte intégral}

\section{$\underline{\text { PDF }} \underline{\text { Signaler ce document }}$}

Bentham on Judicial Reform in Scotland. Profound-original-useless! unintelligible to common readers, and attacks all their prejudices.

The London Literary Gazette July 251835

\section{1: Introduction}

1Facts have a central place in Bentham's ethics. In Bentham and the Ethics of Today, David Baumgardt states plainly that 'It is the very essence of the moral calculus to base moral valuations on a comparison of facts, and not on other valuations.' 1 Baumgardt's distinction between a comparison of facts and 'other valuations', indicates that a utilitarian consciousness is primarily concerned with distinguishing facts from fallacies 2 within particular contexts for thinking and making statements (including statements about ethics) rather than separating fact from fiction, or fiction from an abstract reality. $\underline{3}$ For Bentham, the term 'fact' indicates the shortest cognitive route from sensation to understanding, whereas fallacy produces an inhibition against, or a detour from, this path. On the one hand, a moral calculus that 'rests on fact - and appeals to sense' $\underline{4}$ takes account of the pleasures that are actually experienced, rather than the pleasures that we are told to experience, or those that we are instructed to avoid. On the other hand, Bentham makes it equally plain that this calculating consciousness is often unconscious within the practice of everyday life. While we may impute a calculating consciousness to others, an 'interest begotten prejudice' $\underline{5}$ may prevent us from seeing it at work within ourselves. Paradoxically, the utilitarian consciousness that we need to overcome our prejudices is the very consciousness that prejudice prevents us from attaining. Interest begotten prejudice, as Bentham defined it, is a personal bias in favour of sectional or 'sinister' interests, of the kind that is expressed in an allegiance to common sense notions of virtue. Prejudice is thus an obstacle to the more general 'reformation in the moral' $\underline{6}$ that 
Bentham proposed in A Fragment on Government. The effectiveness of government is thus 'a matter of fact that depends upon experience, and is to be collected by observation.' $\underline{7}$

- 1 Baumgardt, David, Bentham and the Ethics of Today (Princeton NJ, Princeton University Press, 1952) (...)

- 2 See Bentham, Jeremy, The Book of Fallacies: from Unfinished Papers of Jeremy Bentham edited by a $f(\ldots)$

- 3 See Stolzenberg, Nomi Maya, 'Bentham's Theory of Fictions - a "Curious Double Language", Cardozo $S \underline{(\ldots)}$

- 4 Bentham, Jeremy, 'Of Laws in General', University College London Bentham Manuscripts, Box 70, Foli (...)

- 5 See 'Interest Begotten Prejudice' in The Book of Fallacies, Bowring II, pp. 477-8

- 6 Bentham, Jeremy, A Fragment on Government in A Comment on the Commentaries and A Fragment on Gover (...)

- 7 Bentham, J., A Comment on the Commentaries, p. 28

- 8 House of Commons, Report from Select Committee on Arts and Manufactures together with the minutes (...)

- 9 See Romans, Mervyn, 'An Analysis of the Political Complexion of the 1835/6 Select Committee on Art (...)

2This article is primarily concerned with using Bentham's comments on governance, ethics and public taste as a framework with which to analyse the application of utilitarianism to questions of public taste and public pedagogy in Britain in the mid-1830s, in a project for 'the education of the eyes of the people by our own Government' $\underline{8}$ initiated by Benthamites and Philosophical Radicals including John Bowring, Edwin Chadwick, Joseph Hume, George Grote, John Arthur Roebuck, Edward Strutt and Henry Warburton, all of whom were appointed to the Select Committee on Arts and Manufactures in $1835 \underline{9}$. My analysis of this historical period is linked to more recent debates on ethics, pedagogy and public policy, through a discussion of Martha Nussbaum's criticisms of utilitarianism and her promotion of 'moral imagination' in Poetic Justice. Nussbaum's book showed that the prospect of overcoming 'interest begotten prejudice' in key debates on public policy had not improved significantly by the end of the twentieth century. I will also refer briefly to more recent debates on the relationship of taste to public policy, centred around the 'libertarian paternalism' and 'choice architecture' of Richard H. Thaler and Cass R. Sunstein, that employs the idea of using minor changes in the environment to 'nudge' individuals towards pre-determined ethical choices. Although it might appear utilitarian in some ways, 'nudge theory' places us at the opposite pole from Bentham's ethics. 'Nudging' acts 'under the radar' of personal prejudice, and is determined by the moral issue of whether or not to intervene within the domain of personal taste and individual autonomy. Bentham, in contrast, argues that if sovereign power can make rational and logical choices about how to intervene, it will have thereby settled the ethical question of whether to intervene or not. 
3My discussion of the problems attending Bentham's wish to set 'prejudice apart' in discussions of taste, is undertaken with specific reference to the psychoanalyst Jacques Lacan's emphasis on the importance of what he termed 'the utilitarian conversion' in ethics, in his Seminar VII of 1959/60. Lacan's praise for Bentham and the "Theory of Fictions' demonstrates some insight into the importance of Bentham's ethics, while misunderstanding some of its most important features. I argue that Bentham's treatment of fact, rather than fictions, gives us a more precise route to the place of the unconscious in Bentham's thought, as well as a better understanding of a utilitarian consciousness of taste.

\section{2: Taste as Fact}

4In his writing on 'the Influence of Time and Place in Matters of Legislation' of 1780-2, Jeremy Bentham asserted that changing the taste of a nation may be done either on the whim of an individual ruler, or in the name of utility. In the former case, it will produce a great deal of unnecessary pain in the cause of one person's pleasure or displeasure. In the latter case, a new law of public taste can only be valid if submitted to an analysis of its costs and benefits. Custom and prejudice can only be countered with arguments for necessity, and judgments of what is good for the public must be founded on the facts of public interest, not the whims of a sovereign. It is crucial to note that the principles of utility that Bentham applied to sovereign power also applied to individuals and communities, with their entrenched prejudices and time-honoured customs. One consequence of this is that Bentham, whether he intended to or not, left the way open for new inventions of taste based on the alignment of tastes and reasons. He rejected the idea that the moral problem of laws of taste is that they intervene arbitrarily on established customs and practices 'for what act or what habit is it that a law can be made against, and that might not be the act of the nation in general were it not for the law?' 10 There can be no arguments against entirely new inventions of taste, which are correlated with a variety of contingent reasons, rather than a culturally limited number of local agreements that constitute the fabric of custom and habit. If tastes are laws, and laws are a coded assemblage of signs, this also undermines the whims of the legislator:

- 10 Bentham, Jeremy, 'Influence of Time and Place', University College London Bentham Manuscripts, Box (...)

- 11 Bentham, Jeremy, 'Rules Respecting the Method of Transplanting Laws', University College London $\mathrm{Be} \underline{(\ldots)}$

If my taste is a sufficient reason for me, an opposite taste may be as sufficient a reason for another. The emperor who would proscribe one letter of the alphabet, should recollect that his successor may determine to restore it: Queen Elizabeth, who was so anxious about the dress of the clergy, should have remembered that it might as easily be allowed in the following reign. 11

- 12 Bentham, J., 'Rules Respecting the Method of Transplanting Laws', Box 88a, Folio 23a (1780-2) 
5While this might seem to be a simple appeal to the age-old principle of chacun à son goût, it is more a matter of 'each to his own context'. In a footnote to this text, Bentham employs the anecdote of a surgeon who capriciously removes the remaining healthy finger on a damaged hand because 'if this little finger had been left it would have looked ridiculous - This anecdote may serve as an apology for many operators in legislation.' 12 In this anecdote, the maintenance of conventions of taste in an aesthetic encounter, is preferred to the unfamiliar 'look' produced by a utilitarian calculus. Conversely, a Benthamite dismissal of the surgeon's caprice would simultaneously dismiss the aesthetic 'look'. It would allow hands with five, one or no fingers to exist in the field of vision, to be read as the specific products of contingent circumstances.

6It is also important to note that the image of a ruler dismissing a letter of the alphabet on a whim, only to have it replaced by someone else, emphasizes that taste is not simply a personal choice, but also exists as a contingent statement within a signifying system. Paradoxically, it is the level of understanding embodied in the complexity of this signifying system, that offers the shortest route from sovereign power to public utility, whereas the path from personal whim to public utility is made impassible by prejudice. However, the acceptance of this system for tempering desire by judgment, displaces the automatic identification of 'sovereign' individuals with their tastes, and instead offers a network of reasons unfolding in time and across space. Further, the 'laissez-faire' issue of whether sovereign power should or should not intervene in the social field, is conditioned by the idea that if a ruler can correctly discern how to intervene within the fabric of custom and practice, he will have thereby settled the ethical question of whether to intervene or not:

- 13 Bentham, J., 'Influence of Time and Place', Box 88a, Folio 27 (1780-2)

Peter the Great made a law obliging the Russians to cut off their beards and wear their clothes short like Europeans ... The measure says Montesquieu afterwards was tyrannical: the change which he wanted to bring about he should have effected not by making a law but by setting an example. In the making of this law his object was either to gratify his own taste merely . . . by putting the people/men into a dress he liked to see instead of one he did not like to see, or it was to polish them, that is to bring the national character as near as he could to the European which he looked upon as better calculated to make them happy ... Could he have effected the desired change of character without effecting this change in dress? could he have effected the change in dress merely by dressing himself as he wished to see his subjects dress, or by other measures less coercive than this law? ... In all such matters . . . the cautious Statesman will avoid the tone of peremptoriness and decision: his conclusions will always in the final instance be hypothetical. If such and such events are the likeliest to later place? But are they? this is a matter which ought to be stated as accompanied with the degree of uncertainty that belongs to it. $\underline{13}$

- 14 Bentham, Jeremy, The Rationale of Reward (London, John Hunt, 1825), p.208

- 15 Bentham, J., The Rationale of Reward, p.208

7On these principles, Bentham dismissed the notion of 'true' and 'false' taste: 'It is only from custom 
and prejudice that, in matters of taste, we speak of false and true.' 14 In TheRationale of Reward, he nonetheless offers an ethical division in the realm of taste, based on the cognitive difference between fact and fallacy in our estimation of the good: 'There is no taste that deserves the epithet good, unless it be the taste for such employments which, to the pleasure actually produced by them, conjoin some contingent or future utility; there is no taste which deserves to be characterized as bad, unless it be a taste for some occupation which has a mischievous tendency.' 15

- 16 Dardenne, Emilie, 'From Jeremy Bentham to Peter Singer', Revue d'études benthamiennes [En ligne], (...)

- 17 Hazlitt, William, The Spirit of the Age, or Contemporary Portraits (Kendal, The Wordsworth Trust), (...)

- 18 Bentham, J., The Rationale of Reward, p. 206

8This view also affords a particular perspective on what Emilie Dardenne has referred to as the 'impossibly demanding ethic' 16 of utilitarianism, the ultima ratio philosophorum mentioned in Hazlitt's essay on Bentham in The Spirit of the Age 17. Hazlitt had argued that the human mind is unable to embrace utilitarian consciousness, because 'our moral sentiments are made up of sympathies and antipathies, of sense and imagination, of understanding and prejudice' and that to think otherwise is against our nature. Bentham, as I have shown, suggests that custom and prejudice are no more natural than utility, and can be approached from within the cognitive order of a utilitarian calculus. The famous passage 'Prejudice apart, the game of push-pin is of equal value with the arts and sciences of music and poetry. If the game of push-pin furnish more pleasure, it is more valuable than either' 18 from Bentham's The Rationale of Reward, at once identifies the possibility of a utilitarian calculus of tastes, while hinting that all the difficulties of this calculus are presented by the naturalisation of prejudices, rather than by any inherent problems of the calculus itself.

- 19 'Arts-Royal Academy', Hansard, Vol. 29, 14 July 1835, cc 553-62

- 20 See the final Report from the Select Committee on Arts and their Connexion with Manufactures With (...)

9The practical difficulties of establishing a utilitarian calculus of taste, cluster around the central problem of setting 'prejudice apart' and establishing the principle that custom and prejudice are no more natural than utility. As I will show in my concluding references to the 'nudge' theories of Sunstein and Thaler, this principle is no more accepted within public policy debates today than it was two centuries ago. Nonetheless, the comments on individual sovereignty, law and public taste that Bentham made between 1780-82, provide a framework for analyzing the efforts of the Benthamites and Philosophical Radicals who sat on the Select Committee on Arts and Manufactures of 1835/6, and others such as Henry Cole who followed in their wake, to find a formula for 'the education of the eyes of the people by our own government'. The Select Committee on Arts and Manufactures was established on 14 July 1835, when MPs John Bowring, Joseph Hume, William Warburton, Thomas Wyse and others, supported William Ewart's motion 'That a Select Committee be appointed to inquire into the best means of extending a knowledge of the Fine Arts, and of the Principles of Design among the people-especially 
among the manufacturing population of the country; and also, to inquire into the constitution of the Royal Academy, and the effects produced by it.' 19 Ewart's motion was successful, and led to the establishment of the Select Committee, and the foundation of the first publicly funded art school, The School of Design, in 1837. This was the first time that a cultural institution (the Royal Academy of Arts) had been criticized, analysed and 'decoded' using criteria of political economic reasoning and public utility, and recoded in a new, publicly funded art institution (The School of Design) directed to the enhancement of public taste in the cause of liberalism and free trade. $\underline{20}$

- 21 'National Education', Hansard, Vol. 20, 30 July 1833, cc 139-74

10Ewart and Bowring were the mainstays of this Committee; both were included in an imaginary 'Radical Philosophical' cabinet proposed by The Spectator in 1837, which also included George Grote, Joseph Hume, Edward Strutt and Henry Warburton, all of whom were initially appointed to the Select Committee on Arts and Manufactures. Another early appointee to the Committee was John Arthur Roebuck, who had argued for the admission of artisans to the planned National Gallery in 1834, and who, in a debate on 'National Education' in 1833, had linked the necessity of the education of the people with 'such knowledge as would create a taste for art'21. In 1837, the same year that the first publicly funded art school was established, Roebuck made a speech on the subject of democracy in Canada, that used Bentham's notion of 'interest begotten prejudice' to describe the political bias that stood in the way of democratic reform:

- 22 'Canada', Hansard, Vol. 37, 14 April 1837, cc 1209-90. See also Bentham, J., The Book of Fallacies $\underline{(\ldots)}$

it requires a powerful effort of the judgment - a superiority to established prejudices of feeling and thought, very rare in this or in any other country, to throw off our inbred respect for the House of Parliament; and to see that what has been taught to us in our cradle and in our youth are the phantoms of a misdirected imagination - the lusty offspring of what Bentham called "an interest-begotten prejudice". $\underline{22}$

- 23 Arts-Royal Academy', Hansard, cc 555-6

11When the Select Committee on Arts and Manufactures was formed in 1835, William Ewart made it clear that the reason for the unusually large number of MPs appointed to it, was 'To have as many practical and professional Gentlemen on the Committee' $\underline{23}$ as possible, aiming to reduce any inherent bias against reform. The larger issue of the relation of interest begotten prejudice to the specific problems of 'the education of the eyes of the people' can be inferred from a satire on the democratic ambitions of the Philosophical Radicals by Albany Fonblanque in the Examiner in 1838. Fonblanque compared the attitudes of the Philosophical Radicals towards the general populace to that of an artist engaged in painting lions, who had visited the menagerie in order to see one for the first time: 
- 24 Albany Fonblanque in the Examiner Dec 16 1838, quoted in Hamburger, Joseph, Intellectuals in Polit (...)

to see in the flesh the quadruped he had spent his days in painting . . . and, in answer to his eager inquiries for the lions, when the noble beasts were shown to him he flew into a violent passion, charged the keeper with cheating the public, and insisted the lions were no lions, for, said he, "I have been painting lions all my life, and should know pretty well what they are like." $\underline{24}$

- 25 See the arguments of Thomas Wyse in support of William Ewart's proposal for a Select Committee on $\underline{(\ldots)}$

12In Fonblanque's view, the Philosophical Radicals, in the name of democracy, had developed an unnatural vision that could not be understood by anyone else. However, it is also significant that, in Fonblanque's satire, the mistake of the Philosophical Radicals is to assume that they can represent something without encountering it. In the view of Philosophical Radicals, on the other hand, 'ways of seeing' were constructed from cultivated forms of aesthetic encounter from which the majority of the population were excluded. $\underline{25}$

- 26 Chadwick, Edwin, review of 'Report from the Select Committee on Arts and Manufactures 1836', The L (...)

- 27 Chadwick, E., The London and Westminster Review, p. 131

- 28 H.C. [Henry Cole] 'Committees of the House of Commons - Administration by Large Numbers', The Lond (...)

- 29 See 'Henry Cole Diaries 1822-1882', a transcript compiled by Elizabeth Bonython, (London, Victoria $($....)

- 30 Austin, John, The Province of Jurisprudence Determined, ed. W. E. Rumble (Cambridge, Cambridge Uni (...)

- 31 'Henry Cole Diaries 1822-1882', entry for 29 Jan 1852: 'Saw Sir C Trevelyan congratulated me on su (...)

13In the same year as Fonblanque's satire in the Examiner, Edwin Chadwick delivered an assessment of the efforts of the Select Committee on Arts and Manufactures in The London and Westminster Review 26, which illustrated some of the intellectual problems involved in refuting Fonblanque's criticisms. While referring to the 'broad and Philosophical' view the Committee had brought to the relation of art, social science and commerce, Chadwick saw this simply in terms of an alliance between the cultivation of a correct taste and an improvement in the position of British manufacturers in foreign markets. He argued that taste had been proved to belong to the province of political economy, and that the creation of tastes was a legitimate branch of commercial industry. Chadwick could be said to be following Bentham's lead somewhat in opposing national prejudices of taste to international commercial success, and positioning the public funding of art education as the outcome of a rational experiment or hypothesis in the education of taste. However, Chadwick's notion of taste prejudices is based on crude 
divisions of class (" the selfish and exclusive classes, who have endeavored to keep back the industrious classes from a knowledge of the principles and refinements of taste, have in reality "picked their own pockets"'27). Chadwick does not address the primary political problem that William Ewart had forseen in his choice of 'practical and professional gentlemen' for the Select Committee on Arts and Manufactures, namely how to close the gap between sectarian prejudice and public interest in the formulation of new institutions of art and a general education in taste. For Chadwick, the agency of the government in deciding on this new pedagogy of taste was simply to arbitrate in favour of the laboring classes. Chadwick's friend Henry Cole, the only person to actually propose new laws of taste in the name of utility, did so after having carefully analysed the composition of the Select Committee of Arts and Manufactures, with an eye to how the House of Commons could more clearly express its own meaning and perfect 'the construction and language of its Acts.' 28 In this regard, it is worth noting that Cole attended John Austin's final series of lectures on 'The Province of Jurisprudence Explained' in January 1833, and read the lectures in their published form.29 In the third lecture of 'The Province of Jurisprudence Explained', Austin argues that definitions of what is good in culture are often made in defence of sectional and partial interests, and that what is required is an education in 'indifferency' and the principles of general utility $\underline{30}$. Austin further argues that it is the obstacles of prejudice and sinister interest placed in the way of the wider cultivation of 'indifferency' that is the true source of the apparent intellectual difficulty of utilitarian ethics. The tenor of Austin's lectures, and the context provided by Henry Cole's friendship with the Mills, may give some indication as to why Cole's later development of 'Principles of Taste' in the Department of Practical Art, favoured correct principles of conduct, based on the identification of fallacies of taste. For Cole, the correspondence between persons and tastes had first to be read through a distinction between facts and fallacies of taste, which could be identified in manufactured objects. However, there is an unresolved tension between 'coded taste' (an appeal to utilitarian consciousness) and 'regulated taste' (representations of utility) in Cole's theories of design reform. When Cole was appointed to 'direct the Art of the Country' 31 in 1852, and declared that a water jug with a pattern of water reeds designed by Richard Redgrave (his colleague in the Department of Practical Art) exemplified 'Correct Principles of Taste', he confused the contingent correlation of taste and reason (the unambiguously coded jug) with the creation of a set of fixed 'reasons' or rules (The Principles of Taste) that introduced the arbitrary whims of Cole as the current 'Tsar' of public taste. Despite the emphasis on linguistic terms such as 'The Grammar of Ornament' in the Department of Practical Art, what Cole disregarded in his discourses on utility, was the mediating role of space, time and language in politics, that Bentham had identified in the image of the ruler who deletes one letter of the alphabet only to have it replaced by his successor.

- 32 See Fielding, K.J., 'Charles Dickens and the Department of Practical Art' The Modern Language Revi (...)

14In following the vicissitudes of Cole's efforts to reform public taste, an important point of reference is Hard Times, chapter two of which is devoted to Charles Dickens's satire on the implausibility of utilitarian design reform, in which the anonymous 'third gentleman' who accompanies Mr Gradgrind in his schoolroom, is partly based on Henry Cole $\underline{22}$. The third gentleman makes a speech to the children of Coketown: 
- 33 Dickens, C., Hard Times, p. 51

'Why, then, you are not to see anywhere, what you don't see in fact; you are not to have anywhere, what you don't have in fact. What is called Taste, is only another name for Fact'. . 'This is a new principle, a discovery, a great discovery,' said the gentleman. $\underline{33}$

15In a letter to Cole on 17 June 1854, Dickens made it clear that what he was satirizing was that, despite his moral intentions and his dedication to reason, Gradgrind goes too far in assuming that taste could be rendered as fact:

- 34 Letter from Charles Dickens to Henry Cole, reproduced in Frayling, Christopher, Henry Cole and the (...)

I often say to Mr Gradgrind that there is reason and a good intention in much that he does - in fact, in all that he does - but that he overdoes it. Perhaps by dint of his going his way and my going mine, we shall meet at last at some halfway house where there are flowers on the carpets, and a little standing-room for Queen Mab's chariot among the Steam Engines. 34

16 Here, Dickens's common sense assumptions about 'overdoing it', were established by comparing hard fact and imaginative fancy, suggesting a halfway house between them. From Bentham's point of view, however, Cole's only problem would have been to what extent he might overcome custom and prejudice in matters of taste and establish taste as a matter of contingent reasons correlated with a multitude of forms. What Cole actually established, however, was a limited number of representations of utility in taste, thus making utility itself into a caprice - a halfway house to Bentham that was also a halfway house to Dickens. In the end, Cole's regulated taste could only offer a means to control and administrate the aesthetic encounter, by employing representations of utility in the name of public education. Bentham, by analysing individual tastes within a comparison and calculus of interests, questions the need for any aesthetic encounter at all. Nonetheless, some potential for a utilitarian consciousness of taste was present in Cole's carefully coded definitions of the fallacies of commercially produced taste, and his engagement with taste across the entire social field, including everyday items such as wallpaper, gas burners and tea trays.

\section{3: The Unconscious}

17If Henry Cole never found a satisfactory way to distinguish reason from prejudice in his analysis of taste, how is this to be accomplished? In 'rules respecting the method of transplanting laws', Bentham had argued that the task of correctly discerning how to intervene in the domain of public taste fell to the legislator. If the legislator chose correctly, personal prejudice and the inertia of custom would be eliminated, and public benefit would be the result. To do this, however, the legislator must circumvent personal whims by choosing not a particular option (a particular letter of the alphabet), but an entire 
method (the utilitarian calculus) and its associated consciousness of space and time. This dimension is the 'intimate converse with the inhabitants of the Moon' referred to In Hazlitt's essay on Bentham, which Hazlitt saw as impossible because 'our feelings evaporate in so large a space' $\underline{35}$. Yet the gauntlet Bentham throws down is precisely that we should choose the utilitarian calculus itself, and take the consequences for our amour propre. Accordingly, Bentham positions a utilitarian calculus as something that is unconscious within everyday consciousness, rather than (as Hazlitt argues) being humanly impossible.

- 35 Hazlitt, W., The Spirit of the Age, p. 94

- 36 In Bentham and the Ethics of Today, p. 379, David Baumgardt refers to remarks that Bentham makes i (...)

18Making this distinction between the unconscious and the impossible, requires particular attention to the place of fact in utilitarian ethics. Specifically, we must note the difference between Bentham's use of the word 'unconscious' to indicate a simple 'ignorance of the facts' resulting from cognitive deficiency or a lack of transparency, and the deflection or 'inhibition' $\underline{36}$ of a utilitarian consciousness of fact by interest begotten prejudice. Some light can be shed on this issue by referring to the particular inhibitions of J.S. Mill, who famously indicated 'a blank in Bentham's system' of ethical judgment in the London and Westminster Review in 1838. In his criticisms of Bentham, Mill introduced two different kinds of 'fact' -'facts in human life' on the one hand, and 'worldly circumstances' on the other:

- 37 Anonymous [John Stuart Mill] review of 'The Works of Jeremy Bentham', The London and Westminster $R \underline{(\ldots)}$

A moralist on Bentham's principles may get as far as this, that we ought not to slay, burn or steal; but what will be his qualifications for regulating the nicer shades of human behaviour, or for laying down even the greater moralities as to those facts in human life which influence the depths of the character quite independently of any influence of worldly circumstances - such, for instance, as the sexual relations, or those of family in general ... It is fortunate for the world that Bentham's taste lay rather in the direction of jurisprudential than of ethical inquiry. $\underline{37}$

19In line with the throwaway comment on 'Bentham's taste' in this passage, Mill also refers disapprovingly to Bentham's single-minded application of a utilitarian moral calculus to all matters, including judgments of taste. In contrast, Mill identifies personal taste as an important index of moral character; taste is the mirror of human nature, and Bentham's taste for jurisprudence tells us something about Bentham's morals. However, what Mill interprets as Bentham's monomania, can also be read as an ethical distinction between fact and fallacy, as applied to judgments of taste. While Bentham did employ processual distinctions within an ethical consciousness in which 'facts conjectured' were developed from 'facts experienced', this consciousness did not rely on the distinction between human and worldly facts that was employed by J. S. Mill. In his discussion of the subjects of law in Of Laws in General, for example, Bentham initially makes a primary distinction between things, which have 
physical properties, and 'persons' that also possess faculties of sensation, perception and volition. He then adds a note to indicate that this definition of a 'person' actually derives from the fundamental distinction between animate cognition and its absence:

- 38 Bentham, Jeremy, Of Laws in General, ed. H.L.A Hart (University of London: Athlone Press 1970) p.3 (...)

Of the inferior animals I omit for shortness' sake to make any particular mention; in so far as their mental faculties are taken into the account, they stand upon a footing with persons; in as far as they are not taken into the account, they stand on a footing with inanimate things. $\underline{38}$

20Accordingly, Bentham's social psychology, as it was presented by Peregrine Bingham in the treatment of 'interest begotten prejudice' in The Book of Fallacies, is not concerned with the formation and development of a character, so much as the fallacies that are instituted by adopting one. Bentham claims that while it is in our personal interest to know what motivates others, it is in our social interest not to acknowledge our own motivations. The unconscious aspects of the person are a product of the formation of character and identity within the social field, and the consequent division of our virtuous self-image from the corrupt web of worldly circumstances in which we see others, but not ourselves, as being enmeshed:

- 39 Bentham, J., The Book of Fallacies, Bowring II, p. 477-8

Not unfrequently, as between two persons living together in a state of intimacy, either or each may possess a more correct and complete view of the motives by which the mind of the other, than of those by which his own mind, is governed. $\underline{39}$

- 40 Bentham, J., The Book of Fallacies, Bowring II, p. 477-8

$21 \mathrm{We}$ are utilitarians with our partners and neighbours, but not with ourselves. Our personal motivations are repellent, and cannot be openly defended; publicly asserted and commonly recognized virtues obscure them: 'Why undeceive himself, and substitute a whole truth, that would mortify him, for a half truth that flatters him?' 40 It is important to note that 'the whole truth' referred to here has nothing to do with an accommodation to the iron circumstances of the world. Rather, it is concerned with the acceptance of a rational evaluation or comparison of our own motivations and interests and those of others. In this case, a primary distinction between animate cognition and its absence, rather than a problem of correspondence between mind and world, is the basis of our consciousness of others and of ourselves. This consciousness will inevitably produce an ethical distinction between the facts of experienced pleasure and the fallacies of public prejudice. A limited insight into the value of this kind of utilitarian consciousness was provided by the psychoanalyst Jacques Lacan in his discussion of Bentham's ethics in his Seminar VII of 1959/60:

- 41 Lacan, Jacques, Le Séminaire de Jacques Lacan: Livre VII L'Éthique de la Psychanalyse 
$1959-1960, \underline{(\ldots)}$

- 42 Lacan, Jacques, The Ethics of Psychoanalysis 1959-1960 The Seminar of Jacques Lacan, Book VII, ed. (...)

I began my lecture this year with the onerous topic of the utilitarians, but the utilitarians are quite right. [ont tout à fait raison 41] They are countered with something which makes the task of countering them much more difficult, with a sentence such as 'But Mr Bentham, my good is not the same as another's good, and your principle of the greatest good for the greatest number comes up against the demands of my egoism." But it's not true. My egoism is content with a certain altruism, altruism of the kind that is situated at the level of the useful. And it even becomes the pretext by means of which I can avoid taking up the problem of the evil I desire, and that my neighbor desires also. $\underline{42}$

22Here, Lacan's analysis demonstrates the opportunities and pitfalls of an intuitive approach to Bentham's ethics in the context of a seminar, the publication of which has also produced disputes over accurate transcription and translation. On the one hand, Lacan can be credited with understanding that an apparent contradiction between 'egoism' and the 'the greatest good of the greatest number' does not constitute an effective argument against Bentham. On the other hand, in the struggle between desire and altruism, altruism is situated 'at the level of the useful' ('au niveau de l'utile') which equates utility with instrumentalism, and ignores Bentham's distinction between the facts of interest and the fallacies of altruism. This may be because Lacan, in his introduction of Bentham and utility at the beginning of Seminar VII, shows a preference for a distinction of fiction and reality, and ignores the alliance of fact and fiction against fallacy in Bentham's moral calculus:

- 43 De Kesel, Marc, Eros and Ethics: Reading Lacan's Seminar VII, trans. Sigi Jöttkandt, (New York, SU (...)

It is in the dialectical relation of language and the real that Bentham tried to give place to the real good, $\mathrm{i}$. e., to the pleasure which (as we will see) he ascribes a function that differs radically from what Aristotle meant by this. And in his emphasis on the opposition between fiction and reality, I will declare, lies the break inaugurated by the Freudian experience. $\underline{43}$

- 44 Lacan, J., Le Séminaire de Jacques Lacan: Livre VII, p. 22

- 45 Lacan, J., The Ethics of Psychoanalysis, p. 12

23The translation reproduced here is by Marc De Kesel, who uses it to question Jacques-Alain Miller's treatment of the same passage in the official edition of Seminar VII, where Miller offers the following: 'Bentham's effort is located in the dialectic of the relationship of language to the real so as to situate the good ... on the side of the real [du côte du réel44].' $\underline{45}$ It can also be argued that De Kesel and Miller are both, in slightly different ways, faithful to Lacan's misreading of Bentham. De Kesel makes some good observations on the distinction between Bentham's ethics of happiness and the Aristotelian emphasis on happiness 'as a natural inclination to let man know he is on the right path towards his ontological 
realization.' However, De Kesel then maps this opposition between virtue ethical naturalism and Benthamite artifice, onto a separate distinction between fiction and reality:

- 46 De Kesel, M., Eros and Ethics, p. 62

What utilitarianism makes into a such an irreversible milestone in our modern moral history is thus not the maxim of "the greatest happiness for the greatest number of people," but the claim that happiness and the good are "fictitious" (i.e., purely signifiers). $\underline{46}$

24The opposition between fiction and reality that de Kesel uses here, shrinks utilitarianism back towards a problem of correspondence between mind and world. The opposition of fact and fallacy, on the other hand, establishes a different ethical consciousness, in which a complex and 'artificial' web of signification that is the basis of a utilitarian calculus, is offered as the moral alternative to a detour into the problem of a correspondence between mind and world.

- 47 This misreading has been compounded by Slavoj Žižek, who in his Tarrying with the Negative: Kant, (...)

25Further, it is this detour into the correspondence between mind and world, that is naturalised in the personal drama of an aesthetic encounter. In Lacan's ethics seminar, despite his praise for the 'utilitarian conversion', aesthetics is presented, contradictorily, both as a detour on the way to desire and as the straightest route towards it. Lacan's analysis of utilitarianism remains unresolved, because it is grounded in the opposition between fiction and reality $\underline{47}$. Bentham's approach is more direct - a consciousness of facts indicates a harmony of will and understanding that promotes the efficiency of desire; fallacies, such as those promoted by critics of taste, can only cloud our perception of our desires. Nonetheless, Lacan's description of Freudian sublimation as a way of choosing 'everything' (the network of signifiers) in the very act of choosing something (a particular object) is closer to the distinction of fact and fallacy than it is to the opposition of fiction and reality. It also relates to Bentham's implication, in 'Rules Respecting the Method of Transplanting Laws', that we must choose the whole alphabet, rather than simply choosing the particular letter that marks our personal contribution, in order to generate complete freedom in the calculation of possibilities and hypotheses. Lacan expresses this idea in the following way:

- 48 Lacan, J., The Ethics of Psychoanalysis, p. 295

It is in the signifier and insofar as the subject articulates a signifying chain that he comes up against the fact that he may disappear from the chain of what he is. $\underline{48}$

26At the end of his seminar on ethics, Lacan concludes that the important thing is not to decide whether a man is good or bad, but to know what the consequences will be when he has 'chosen everything' by aligning his actions with the field of signification. The natural limits of ethics in Aristotle, which are the limits of the self in its relation to the world, are here replaced by the framing of ethical judgments in 
terms of logic and language that has been enabled by 'la conversion utilitariste'. The necessity of this 'connversion' is why, as I have argued, Bentham positions a utilitarian calculus as something that is unconscious within everyday consciousness, rather than (as Hazlitt claims) being humanly impossible. In a commentary on Hazlitt's essay on Bentham, Tim Milnes has pointed out that in aligning common sense with aesthetic performance, Hazlitt shows himself to be promoting obscurity within a conventional epistemological framework:

- 49 Milnes, Tim, 'Darkening Knowledge' : Hazlitt and Bentham on the Limits of Empiricism' in Metaphys (...)

The irony within Hazlitt's irony in 'Bentham' and 'On People of Sense', then, is that his critique of Bentham's supposedly thin, non-performative prose take the form of a performance that, rather than dispensing with the notion of a 'correspondence' between mind and world, reinscribes this correspondence in the crepuscular grounds of common sense. $\underline{49}$

27Following the death of Hazlitt in 1830 and Bentham in 1832, the challenge for the members of the Select Committee on Arts and Manufactures, and their legatee Henry Cole, was to establish public taste and public education on something other than 'the crepuscular grounds of common sense'. That this project failed, and that all of this activity by the radical thinkers at the Board of Trade in the 1830s resulted in nothing more than some attempts to establish government regulation of the aesthetic encounter, should not be a reason for ignoring their efforts. Where Hazlitt argued that transcending common sense and common prejudice was impossible, Bentham claimed that it was necessary, in order that those in power could have the expanded temporal and spatial framework of the utilitarian calculus at their disposal, as well as the ability to construct effective hypotheses on social and cultural change. The concluding section of this article looks at some of the conditions of more recent debate on the relationship of utilitarianism and public policy, to ask whether these possibilities have been realized in the present.

\section{4: Conclusion - the task of the legislator}

28In 'Rules Respecting the Method of Transplanting Laws', Bentham makes it clear that the task of the legislator on public taste is to align himself with an 'alphabet' or sequence of tastes, in order to make an ethical choice within the terms of a utilitarian consciousness. In contrast, the ruler who chooses on a whim chooses blindly, with no awareness of the sequence in which he is unconsciously enmeshed, or the sinister interests that may be affecting his judgment. Utilitarian consciousness may be unconscious within personal prejudices of taste, but this does not mean that a utilitarian consciousness of taste is impossible. However, this consciousness occupies an unusual position within the debates on free trade and laissez-faire economics that determined the efforts of the Select Committee on Arts and Manufactures in the mid-1830s. It sits athwart the gap between Adam Smith's virtue ethical notion of happiness as the sign of human self-realisation in the world of goods, and Bentham's definition of happiness according to the distinction between animate cognition and its absence, which was caricatured 
in J. S. Mill's scathing reference to the 'pig satisfied' $\underline{50}$. It can be argued that for Bentham, the initiation of laissez-faire paradoxically depends on a decision which is made in favour of the utilitarian calculus, and against prejudice and inertia. This decision is difficult to make, or even to understand, in a situation where virtue ethics is privileged over utility, and the relation of mind and world shapes our identity and our common sense views on social and cultural issues. An example of this prejudice at work in recent debates on political economy and public policy can be found in Martha Nussbaum's references, in her book Poetic Justice, to Dickens's criticisms of utilitarianism in Hard Times. In Poetic Justice, Nussbaum argues that Hard Times is an example of how great literature can be employed to promote the moral imagination (a notion that Nussbaum adapts from Adam Smith's Theory of Moral Sentiments) against what she sees as the 'refusal of sympathy' and anti-humanism in aspects of utilitarian thought. In pursuing her argument, Nussbaum employs a version of Hazlitt's criticism of utilitarianism, namely that utilitarianism is a theory that is revealed to be implausible, impossible or bizarre when applied to ethical practice in everyday life or the inner life of individuals, and that what is lacking in Bentham is a 'fuller vision of persons' $\underline{51}$ :

- 50 Mill, J.S., Utilitarianism (London, Longmans, Green and Reader 1871), p.14

- 51 Nussbaum, Martha, Poetic Justice: The Literary Imagination and Public Life (Boston, Beacon Press 1 (...)

- 52 Nussbaum, M., Poetic Justice, p.17

The utilitarian picture of human beings and of rationality is familiar enough in theory. What makes the utilitarian norm appear so odd to the reader of Dicken's novel is that it is taken seriously all the way down, so to speak: understood not just as a way of writing up reports, but as a way of dealing with people in daily encounters; not just as a way of doing economics, but as a way of defining a horse or talking to a child; not just as a way of being professionally respectable, but as a commitment that determines the whole content of one's personal and social life. But since this norm does in fact claim to be a standard of rationality, and not just a handy professional tool, and since, if it really is a norm, it also seems fair to ask people to abide by it consistently, it also seems perfectly fair to ask what people who really and thoroughly saw the world in the way this norm recommends would be like. $\underline{52}$

29In one sense, Nussbaum is perfectly correct - the 'strangeness' of utilitarian ethics must be accounted for. On the other hand, while accepting that Hard Times is satirical fiction, she is inclined to accept Dickens's opposition of fact and fancy as the foundation of her arguments against utilitarianism. We can also take up Nussbaum's challenge to take utilitarianism seriously 'all the way down' and, moving away from the prevarications of Henry Cole, ask 'what is the 'seeing in fact' that the third gentleman refers to in Hard Times?' To do this one would also have ask what the status of 'fact' is within utilitarian ethics, rather than within the novels of Charles Dickens. As I have argued, 'seeing in fact' would be the shortest route to sense afforded by an avoidance of those aesthetic encounters on which the 'noble exemplars' of virtue ethics rely. A model of 'seeing in fact' is offered in Bentham's description of the public gymnasium in his Deontology: 
- 53 Bentham, Jeremy, Deontology, ed. John Bowring (London: Longman, Rees, Orme, Brown, Green and Longm (...)

A whole kingdom, the great globe itself, will become a gymnasium, in which every man exercises himself before the eyes of every other man. Every gesture, every turn of limb or feature, in those whose motions have a visible influence on the general happiness, will be noticed and marked down. The constitution of the human mind being opened by degrees, the labyrinth is explored, a clue is found out for it. That clue is the influence of interest; of interest, not in that partial and sordid sense in which it is the tyrant of sordid souls, but in the enlarged and beneficent sense in which it is the common master of all spirits, and especially of the enlightened. It is put into the hands of every man. 53

- 54 Bentham, Jeremy, Offences Against Oneself, available at: http://www.columbia. [Accessed 14 Februar (...)

- 55 Nussbaum, M., Poetic Justice, p.17

30'Seeing in fact' would also depend on a consciousness in which custom and prejudice are no more natural than utility. When Bentham writes on 'Offences Against Oneself', for example, he paradoxically refers to his efforts to find sufficient grounds for prejudice, in the face of a utilitarian calculus that can discover none54. In this regard, and with reference to Bentham's comments in The Book of Fallacies, is worth contrasting Bentham's struggle to accept the claims of prejudice against those of a calculus of sexual pleasure, with the ease with which Martha Nussbaum infers a calculating consciousness to Richard Posner's 'Gradgrindian account of sexual choices' 55 in his Sex and Reason, while defending an ethics of character. Nussbaum offers Posner's text as proof that Gradgrindism actually exists as an element of public policy; in other words she is claiming that the opposition between fact and fancy she has incarnated in Dickens is 'real'. From the correlationist perspective offered by virtue ethics, utilitarianism is a theory of choice whose implications are unethical. When Bentham writes about 'Offences Against Oneself', on the other hand, he makes it clear that the ethical choice is between fact and fallacy, or in other words between utilitarianism and prejudice.

- 56 Thaler, Richard H. and Sunstein, Cass R., Nudge: Improving Decisions about Health, Wealth and Happ (...)

- 57 Thaler, R. H., and Sunstein, C. R., Nudge, p.9

31 Nussbaum's preference for 'fancy' and the aesthetic encounter, shows a bias in favour of virtue ethics over utilitarianism in public policy debates that has continued into the present. The current popularity of the 'nudge' theories of Richard H. Thaler and Cass R. Sunstein with governments on both sides of the Atlantic, shows that current thinking on the relation of government agency to individual tastes is divided against itself $\underline{56}$. 'Nudging' 'libertarian paternalism' and 'choice architecture' favour the introduction of small changes in the design of human environments that enable individuals to promote public good without being aware of it. While 'nudge' might seem to be an example of 'indirect legislation' by Bentham's definition of the term, it acts with inertia and prejudice rather than against them. Thaler and Sunstein advise us that we should "never underestimate the power of inertia. Second, that power can be 
harnessed. If private companies or public officials think that one policy produces better outcomes, they can greatly influence the outcome by choosing it as the default.' $\underline{77}$ As happened with Henry Cole's efforts with design reform and public pedagogy in the nineteenth century, 'nudgism' can do no more than attempt to regulate our tastes, while keeping the signifying system of 'choice architecture' at an unconscious level. Sunstein and Thaler's theories are also directed towards the limitation of choices and tastes according to pre-determined ethical conventions. In contrast, Bentham's 'alphabet' of tastes used logic and language to propose a reform of ethics. This is achieved by a decision in favour of the utilitarian calculus, or to use Sunstein and Thaler's terms, a choice in favour of 'choice architecture' itself.

$\underline{\text { Haut de page }}$

\section{Bibliographie}

[John Stuart Mill] review of 'The Works of Jeremy Bentham', The London and Westminster Review, 31:2 (1838) pp. 467- 506

Austin, John The Province of Jurisprudence Determined, ed. W. E. Rumble (Cambridge, Cambridge University Press 1995)

Baumgardt, David, Bentham and the Ethics of Today (Princeton NJ, Princeton University Press, 1952)

Bentham, Jeremy, Offences Against Oneself, available at: http://www.columbia.edu/cu/lweb/eresources/ exhibitions/sw25/bentham/index.html [Accessed 14 February 2011]

Bentham, Jeremy, A Fragment on Government, in A Comment on the Commentaries and A Fragment on Government, eds. J.H. Burns and H.L.A. Hart (Oxford, Clarendon Press, 2008)

Bentham, Jeremy, Of Laws in General, ed. H.L.A Hart (University of London, Athlone Press 1970)

Bentham, Jeremy, The Works of Jeremy Bentham, ed. J. Bowring (Edinburgh, 1838 -1843)

Bentham, Jeremy, Deontology, ed. John Bowring (London, Longman, Rees, Orme, Brown, Green and Longman 1834) vol.1

Bentham, Jeremy, The Rationale of Reward (London, John Hunt, 1825)

Chadwick, Edwin, review of 'Report from the Select Committee on Arts and Manufactures 1836', The London and Westminster Review, July 1837, pp. 116-139

Dardenne, Emilie, 'From Jeremy Bentham to Peter Singer', Revue d'études Benthamiennes [En ligne], 7 
| 2010, mis en ligne le 13 septembre 2010. URL : http://etudes-benthamiennes.revues.org/204

De Kesel, Marc Eros and Ethics: Reading Lacan's Seminar VII, trans. Sigi Jöttkandt, (New York, SUNY Press 2009)

Dickens, Charles, Hard Times (London, Penguin 1969)

Fielding, K. J., 'Charles Dickens and the Department of Practical Art', The Modern Language Review, 48:3 (1953), pp. 270-277

Frayling, Christopher, Henry Cole and the Chamber of Horrors: the Curious Origins of the Victoria and Albert Museum (London, V\&A Publishing 2010)

Hamburger, Joseph, Intellectuals in Politics: John Stuart Mill and the Philosophic Radicals (New Haven and London, Yale 1965)

Hazlitt, William, The Spirit of the Age, or Contemporary Portraits (Kendal, The Wordsworth Trust)

H.C. [Henry Cole] 'Committees of the House of Commons - Administration by Large Numbers', The London and Westminster Review, Vol. 5, no. 9, April 1837, pp. 209 -25

'Henry Cole Diaries 1822-1882', a transcript compiled by Elizabeth Bonython, London: Victoria and Albert Museum

Heydt, Colin, 'Mill, Bentham and 'Internal Culture', British Journal for the History Of Philosophy,14:2 (2006), pp. 275-301

House of Commons Report from the Select Committee on Arts and their Connexion with Manufactures With the Minutes of Evidence, Appendix and Index (House of Commons, 1836)

House of Commons, Report from Select Committee on Arts and Manufactures together with the minutes of evidence and appendix (House of Commons, 1835)

Lacan, Jacques, The Ethics of Psychoanalysis 1959-1960 The Seminar of Jacques Lacan, Book VII, ed. Jacques-Alain Miller, trans. Dennis Porter (London, Routledge 1992)

Lacan, Jacques, Le Séminaire de Jacques Lacan: Livre VII L'Éthique de la Psychanalyse 1959-1960, texte établi par Jacques-Alain Miller (Paris, Éditions du Seuil 1986)

Mill, John Stuart, Utilitarianism (London, Longmans, Green and Reader 1871) 
Milnes, Tim 'Darkening Knowledge' : Hazlitt and Bentham on the Limits of Empiricism' in Metaphysical Hazlitt, eds. Uttara Natarajan, Tom Paulin and Duncan Wu (London, Routledge 2005)

Nussbaum, Martha, Poetic Justice: The Literary Imagination and Public Life (Boston, Beacon Press 1995)

Quinn, Malcolm, 'The Disambiguation of the Royal Academy of Arts', History of European Ideas, 37 (2011) pp.53-62

Romans, Mervyn, 'An Analysis of the Political Complexion of the 1835/6 Select Committee on Arts and Manufactures, The International Journal of Art and Design Education, 26:2, 2007, pp. 215 -224

Schofield, Philip, Utility and Democracy: The Political Thought of Jeremy Bentham (Oxford, Oxford University Press, 2006)

Stolzenberg, Nomi Maya 'Bentham's Theory of Fictions - a "Curious Double Language"”, Cardozo Studies in Law and Literature, 11:2 (1999), pp. 223-261

Thaler, Richard H. and Sunstein, Cass R., Nudge: Improving Decisions about Health, Wealth and Happiness (London, Penguin 2008)

Žižek, Slavoj, Tarrying with the Negative: Kant, Hegel and the Critique of Ideology (Durham, Duke University Press 1993)

$\underline{\text { Haut de page }}$

\section{Notes}

1 Baumgardt, David, Bentham and the Ethics of Today (Princeton NJ, Princeton University Press, 1952), p. 362. See also Schofield, Philip, Utility and Democracy: The Political Thought of Jeremy Bentham (Oxford, Oxford University Press, 2006), p.40: 'Bentham was quite explicit that an appeal to the principle of utility constituted an appeal to matters of fact.'

2 See Bentham, Jeremy, The Book of Fallacies: from Unfinished Papers of Jeremy Bentham edited by a friend, in The Works of Jeremy Bentham, ed. J. Bowring (Edinburgh, 1838 -1843), vol. II, p.379: 'By the name of fallacy, it is common to designate any argument employed, or topic suggested, for the purpose, or with a probability, of producing the effect of deception - of causing some erroneous opinion to be entertained by any person to whose mind such argument may have been presented.' See also Schofield, P., Utility and Democracy, pp. 156 -157, for a discussion of the distinction between fallacy and 'vulgar errors': 'For instance, to believe that those who lived in old times were, because they lived in those times, wiser or better than those who lived in modern times, was vulgar error; to appeal to that error in 
order to retain some mischievous practice or institution was fallacy.'

$\underline{3}$ See Stolzenberg, Nomi Maya, 'Bentham's Theory of Fictions - a "Curious Double Language", Cardozo Studies in Law and Literature, 11:2 (1999), pp. 223-261, p. 223: 'as Bentham painstakingly demonstrates, fiction and fact are inseparable aspects of the same cognitive process.'

4 Bentham, Jeremy, 'Of Laws in General', University College London Bentham Manuscripts, Box 70, Folio 22 (1773)

$\underline{5}$ See 'Interest Begotten Prejudice' in The Book of Fallacies, Bowring II, pp. 477-8

$\underline{6}$ Bentham, Jeremy, A Fragment on Government in A Comment on the Commentaries and A Fragment on Government, eds. J.H. Burns and H.L.A. Hart (Oxford, Clarendon Press, 2008), p. 393

7 Bentham, J., A Comment on the Commentaries, p. 28

$\underline{8}$ House of Commons, Report from Select Committee on Arts and Manufactures together with the minutes of evidence and appendix (House of Commons, 1835) p.16

9 See Romans, Mervyn, 'An Analysis of the Political Complexion of the 1835/6 Select Committee on Arts and Manufactures', The International Journal of Art and Design Education, $26: 2$ (2007), pp. 215 224

10 Bentham, Jeremy, 'Influence of Time and Place', University College London Bentham Manuscripts, Box 88a Folio 27 (1780-2)

11 Bentham, Jeremy, 'Rules Respecting the Method of Transplanting Laws', University College London Bentham Manuscripts, Box 88a, Folio 23a (1780-2)

12 Bentham, J., 'Rules Respecting the Method of Transplanting Laws', Box 88a, Folio 23a (1780-2)

13 Bentham, J., 'Influence of Time and Place', Box 88a, Folio 27 (1780-2)

14 Bentham, Jeremy, The Rationale of Reward (London, John Hunt, 1825), p.208

15 Bentham, J., The Rationale of Reward, p.208

16 Dardenne, Emilie, 'From Jeremy Bentham to Peter Singer', Revue d'études benthamiennes [En ligne], 7 | 2010, mis en ligne le 13 septembre 2010. URL : http://etudes-benthamiennes.revues.org/204, 1.1 .8 
17 Hazlitt, William, The Spirit of the Age, or Contemporary Portraits (Kendal, The Wordsworth Trust), p.93: 'We are afraid the human mind does not readily come into this doctrine, the ultima ratio philosophorum, interpreted according to the letter. Our moral sentiments are made up of sympathies and antipathies, of sense and imagination, of understanding and prejudice. The soul, by reason of its weakness is an aggregating and exclusive principle; it clings obstinately to some things, and violently rejects others. And it must do so, in a great measure, or it would act contrary to its own nature.'

18 Bentham, J., The Rationale of Reward, p. 206

19 'Arts-Royal Academy', Hansard, Vol. 29, 14 July 1835, cc 553-62

20 See the final Report from the Select Committee on Arts and their Connexion with Manufactures With the Minutes of Evidence, Appendix and Index, House of Commons 16 August 1836, pp. v- viii: 'HM govt has proposed a vote for a 'Normal School of Design' . . [offering] not mere theoretical instruction only, but the direct practical application of the Arts to Manufactures .. It seems probable that the principle of free competition in art (as in commerce) will ultimately triumph over all artificial institutions . . [the Royal Academy of Arts] possesses may of the privileges of a public body, without bearing the direct burthen of public responsibility.' See also Quinn, Malcolm 'The Disambiguation of the Royal Academy of Arts' History of European Ideas, 37 (2011) pp.53-62

21 'National Education', Hansard, Vol. 20, 30 July 1833, cc 139-74

22 'Canada', Hansard, Vol. 37, 14 April 1837, cc 1209-90. See also Bentham, J., The Book of Fallacies, Bowring II, p.459: Even in the present stage of civilization, it is almost a rare case, that by reason, looking to the end in view, matters of government are determined; and the cause is, the existence of so many institutions, which being adverse to the only proper end, the greatest happiness of the greatest number, are maintained, because favourable to the interests of the ruling few. Custom, blind custom, established under the dominion of that separate and sinister interest, is the guide by which most operations have been conducted.'

$\underline{23}$ Arts-Royal Academy', Hansard, cc 555-6

24 Albany Fonblanque in the Examiner Dec 16 1838, quoted in Hamburger, Joseph, Intellectuals in Politics: John Stuart Mill and the Philosophic Radicals (New Haven and London: Yale 1965), p. 263

25 See the arguments of Thomas Wyse in support of William Ewart's proposal for a Select Committee on Arts and Manufactures 'Arts-Royal Academy', Hansard, cc 556-7:' Another consequence of this want of cultivation in the people at large was the general complaint that the middle classes of this country when they go into a gallery of paintings or sculpture, despised and sometimes destroyed the works of art exhibited, merely because they were not early accustomed to a cultivation of those arts. It 
had been apprehended, in consequence of evidence given before the Committee on the British Museum, that such would be the result of a free admission, and restrictions were represented as necessary, which would be altogether uncalled for, if they had commenced at an early period in educating the people.'

26 Chadwick, Edwin, review of 'Report from the Select Committee on Arts and Manufactures 1836', The London and Westminster Review, July 1837, pp. 116-139

27 Chadwick, E., The London and Westminster Review, p. 131

28 H.C. [Henry Cole] 'Committees of the House of Commons - Administration by Large Numbers', The London and Westminster Review, Vol. 5, no. 9, April 1837, pp. 209 -25, p.210: '[the House of Commons] hardly ever succeeds in expressing its own meaning, for want of mere workmanlike and mechanical execution in the construction and language of its Acts.'

29 See 'Henry Cole Diaries 1822-1882', a transcript compiled by Elizabeth Bonython, (London, Victoria and Albert Museum). In his diary entry for 3 January 1833, Cole notes his first attendance at Austin's lectures, which continued throughout that month. On the 24 January, Cole notes that 'Austin prevented by illness from lecturing' and on 5 Feb 1833, 'Reading Austins lectures . . . Afterwards accompanied James Mill to his discufsion clafs [sic].'

30 Austin, John, The Province of Jurisprudence Determined, ed. W. E. Rumble (Cambridge, Cambridge University Press 1995), p.70

$\underline{31}$ 'Henry Cole Diaries 1822-1882', entry for 29 Jan 1852: 'Saw Sir C Trevelyan congratulated me on success: on appointment to direct the Art of the Country.'

32 See Fielding, K.J., 'Charles Dickens and the Department of Practical Art' The Modern Language Review, 48:3 (1953), pp. 270-277. On p. 271, Fielding notes that 'nothing is said to explain why the 'third gentleman' should be in the company of the other two at all . . He is clearly a public official of some kind.' On p.272 he claims that 'Dickens was satirizing the doctrines of the newly-formed Department of Practical Art, and that the figure of the 'third gentleman' originated as a caricature of its superintendent Henry Cole.' Fielding offers as evidence for this claim, the notes that Dickens made for chapter two of Hard Times, which mention 'Mr Gradgrind. Marlborough House Doctrine. Cole.'

$\underline{33}$ Dickens, C., Hard Times, p. 51

34 Letter from Charles Dickens to Henry Cole, reproduced in Frayling, Christopher, Henry Cole and the Chamber of Horrors: the Curious Origins of the Victoria and Albert Museum (London, V\&A Publishing 2010), p. 21

35 Hazlitt, W., The Spirit of the Age, p. 94 
36 In Bentham and the Ethics of Today, p. 379, David Baumgardt refers to remarks that Bentham makes in Rationale of Judicial Evidence, that there is need for an appropriate term to signify the causes of inaction: 'Today the need that Bentham felt has been met. The important term he missed was introduced to psychology by Johann Friedrich Herbart and has gained a central place in the theories of Sigmund Freud ... This term is inhibition.'

37 Anonymous [John Stuart Mill] review of 'The Works of Jeremy Bentham', The London and Westminster Review, 31:2 (1838), pp. 467- 506, p.489. Colin Heydt, in his article 'Mill, Bentham and 'Internal Culture', British Journal for the History Of Philosophy 14 :2 (2006), pp. 275-301, endorses Mill's critique of 'Bentham's shortcomings as an ethicist' (p.301) and Mill's indexing of external traits to the development and education of character

38 Bentham, Jeremy, Of Laws in General, ed. H.L.A Hart (University of London: Athlone Press 1970) p.35 n

39 Bentham, J., The Book of Fallacies, Bowring II, p. 477-8

$\underline{40}$ Bentham, J., The Book of Fallacies, Bowring II, p. 477-8

41 Lacan, Jacques, Le Séminaire de Jacques Lacan: Livre VII L'Éthique de la Psychanalyse 19591960, texte établi par Jacques-Alain Miller (Paris, Éditions du Seuil 1986), p.220

42 Lacan, Jacques, The Ethics of Psychoanalysis 1959-1960 The Seminar of Jacques Lacan, Book VII, ed. Jacques-Alain Miller, trans. Dennis Porter (London, Routledge 1992), p. 182

43 De Kesel, Marc, Eros and Ethics: Reading Lacan's Seminar VII, trans. Sigi Jöttkandt, (New York, SUNY Press 2009), p. 61.

44 Lacan, J., Le Séminaire de Jacques Lacan: Livre VII, p. 22

45 Lacan, J., The Ethics of Psychoanalysis, p. 12

46 De Kesel, M., Eros and Ethics, p. 62

47 This misreading has been compounded by Slavoj Žižek, who in his Tarrying with the Negative: Kant, Hegel and the Critique of Ideology (Durham, Duke University Press 1993) p.87, presents Bentham as an empiricist at heart who reluctantly made 'concessions' to the autonomous operation of language: 'Although Bentham clung to his program of reducing fictions to their real ingredients, he had to concede that in the case of fictions strictu sensu, i.e., fictions as opposed to imaginary nonentities, this reduction 
cannot be carried out; we must proceed differently and reformulate, in the form of a description of real acts, the whole situation designated by the word "contract", for example.'

48 Lacan, J., The Ethics of Psychoanalysis, p. 295

49 Milnes, Tim, "Darkening Knowledge' : Hazlitt and Bentham on the Limits of Empiricism' in Metaphysical Hazlitt, eds. Uttara Natarajan, Tom Paulin and Duncan Wu (London, Routledge 2005), p.135

$\underline{50}$ Mill, J.S., Utilitarianism (London, Longmans, Green and Reader 1871), p.14

51 Nussbaum, Martha, Poetic Justice: The Literary Imagination and Public Life (Boston, Beacon Press 1995), p.33

$\underline{52}$ Nussbaum, M., Poetic Justice, p.17

53 Bentham, Jeremy, Deontology, ed. John Bowring (London: Longman, Rees, Orme, Brown, Green and Longman 1834) vol.1, p.101

54 Bentham, Jeremy, Offences Against Oneself, available at: http://www.columbia.edu/cu/lweb/ eresources/exhibitions/sw25/bentham/index.html [Accessed 14 February 2011] 'I have been tormenting myself for years to find if possible a sufficient ground for treating them [irregularities of the venereal appetite] with the severity with which they are treated at this time of day by all European nations: but upon the principle utility I can find none.'

$\underline{55}$ Nussbaum, M., Poetic Justice, p.17

56 Thaler, Richard H. and Sunstein, Cass R., Nudge: Improving Decisions about Health, Wealth and Happiness (London, Penguin 2008)

57 Thaler, R. H., and Sunstein, C. R., Nudge, p.9

$\underline{\text { Haut de page }}$

\section{Pour citer cet article}

\section{Référence électronique}

Malcolm Quinn, « The Invention of Facts: Bentham's Ethics and the Education of Public Taste », 
Revue d'études benthamiennes [En ligne], 9|2011, mis en ligne le 15 septembre 2011, consulté le 20 septembre 2011. URL : http://etudes-benthamiennes.revues.org/346

Haut de page

\section{Auteur}

\section{Malcolm Quinn}

Reader in Critical Practice, CCW Graduate School, University of the Arts London

$\underline{\text { Haut de page }}$

\section{Droits d'auteur}

Droits réservés

Haut de page

$\underline{\text { Sommaire - Document précédent - Document suivant }}$

\section{Navigation}

\section{Index}

- $\underline{\text { Auteurs }}$

- Index de mots-clés

Numéros en texte intégral

- $9 \mid 2011$

Éthique utilitariste

- $\underline{8 \mid 2011}$

Foucault et l'Utilitarisme

- $7 \underline{2010}$

Varia

- $\underline{6 \mid 2010}$

Autour du manuscrit des Délits religieux 
- $5 \mid 2009$

Varia

- $4 \mid 2008$ Spécial John Stuart Mill

- $\underline{3 \mid 2007}$ Varia

- $\underline{2 \mid 2007}$ Varia

- 112006 Varia

\section{Tous les numéros}

\section{La revue}

- Présentation

- Note aux auteurs

- Comité scientifique

\section{Informations}

- $\underline{\text { Contact }}$

- Crédits

- Appels à contributions: E-nous, Grenade

\section{Syndication}

- R Fil des numéros

- Ri Fil des documents

\section{Lettres d'information}

- Lettre d'information de la Revue d'études benthamiennes

- La Lettre de Revues.org

\section{Affiliations/partenaires}


Les cahiers de Revues.

org

ISSN électronique 1760-7507

$\underline{\text { Plan du site }}-\underline{\text { Contact }}-\underline{\text { Crédits }}-\underline{\text { Flux de syndication }}$

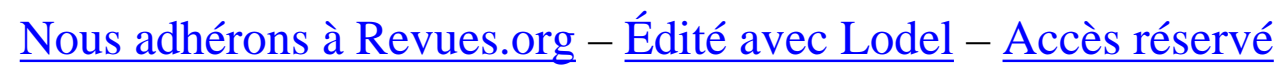

\section{openedition:}

- $\underline{\text { revues.org }}$

- Revues.orgRevues et collections de livres

- Les revues (304)

- Les collections de livres (18)

- En savoir plus

- $\underline{\text { calenda }}$

- CalendaCalendrier des sciences sociales

- Accéder aux événements (16171)

- En savoir plus

- hypotheses.org

- Hypotheses.orgCarnets et blogs de recherche

- Accéder aux carnets (232)

- En savoir plus

- Lettre \& alertes

- LettreS'abonner à la Lettre de Revues.org

- Alertes \& abonnementsAccéder au service

- $\underline{\text { Freemium }}$

Rechercher

\section{Submit Query}

○ Titre :

Revue d'études benthamiennes

En bref :

Publication destinée à diffuser les travaux menés sur la pensée de Jeremy Bentham. A publication gathering studies on the thought of Jeremy Bentham 


\section{Sujets :}

Droit, Esprit et Langage, Pensée, Philosophie

o Dir. de publication :

Jean-Pierre Cléro

Éditeur :

Centre Bentham

Support :

Électronique

EISSN :

1760-7507

- Accès :

Open access Freemium

- DOI / Références

o DOI :

10.4000/etudes-benthamiennes.346

- Citer cette référence

- Outils

- Signaler cet article

- Imprimer cet article 